\title{
Comparison of maximal oxygen uptake and anaerobic threshold in soccer and handball players
}

\author{
Mehmet Soyal $^{1}$, Selcen Korkmaz Eryılmaz ${ }^{2}$, Metin Polat ${ }^{3}$, Sami Aydoğan ${ }^{4}$ \\ ${ }^{1}$ School of Physical Education and Sports, Sakarya University, Sakarya, TURKEY \\ ${ }^{2}$ School of Physical Education and Sports, Cukurova University, Adana, TURKEY \\ ${ }^{3}$ School of Physical Education and Sports, Erciyes University, Kayseri, TURKEY \\ ${ }^{4}$ Division of Sports Physiology, Department of Physiology, \\ Faculty of Medicine, Erciyes University, Kayseri, TURKEY
}

\begin{abstract}
Purpose: $\quad$ The purpose of this study was to compare maximal oxygen uptake and anaerobic threshold values between soccer and handball players.

Material: $\quad 10$ male professional soccer players and 10 male professional handball players took part in the study. Maximal oxygen uptake $\left(\mathrm{VO}_{2 \max }\right)$ and anaerobic threshold (AT) were assessed using an incremental treadmill test. AT was estimated noninvasively using the $\mathrm{V}$-slope method. The values of $\mathrm{VO}_{2}\left(\mathrm{AT}_{\mathrm{VO} 2}\right)$, heart rate $\left(\mathrm{AT}_{\mathrm{HR}}\right)$, time $\left(A T_{\text {TIME }}\right)$ and running speed (AT ${ }_{\text {SPEFn }}$ ) corresponding to the AT were identified. AT was recorded as a percentage of $\mathrm{VO}_{2 \mathrm{max}}(\mathrm{AT}$ $\left.\% \mathrm{VO}_{2 \max }\right)$ and $\mathrm{HR}_{\max }\left(\mathrm{APT} \% \mathrm{HR}_{\max }\right)$. Time to exhaustion was determined as the total duration of the test.

Results: $\quad$ There were no significant difference between the time to exhaustion(min), $\mathrm{HR}_{\text {max }}$, absolute VO $\mathrm{O}_{2 \mathrm{max}}\left(\mathrm{ml}_{\mathrm{min}}^{-1}\right)$ and relative $\mathrm{VO}_{2 \max }\left(\mathrm{ml} \mathrm{kg}^{-1} \mathrm{~min}^{-1}\right)$ of soccer and handball players compared to each other $(\mathrm{p}>0.05)$. Similarly there were no significant difference between the two groups in the AT $T_{\text {SPEEP }}\left(\mathrm{km} \mathrm{h}^{-1}\right), \mathrm{AT}_{\text {TIME }}(\mathrm{min}), \mathrm{AT}_{\mathrm{HR}}$, absolute $\mathrm{AT}_{\mathrm{VO} 2}\left(\mathrm{ml} \mathrm{min}^{-1}\right)$, relative $A_{\text {VO2 }}\left(\mathrm{ml} \mathrm{kg}^{-1} \mathrm{~min}^{-1}\right), \mathrm{AT}_{\% \mathrm{VO}_{2 \max }}$ and $\mathrm{AT} \% \mathrm{HR}_{\max }(\mathrm{PPEE}>0.05)$.

Conclusions: $\quad$ Although soccer and handball require different movement patterns, they may exhibit similar aerobic endurance capacity. Hence physiological requirements in both branches may be expected to be similar in relation to training volume and intensity.

Keywords: $\quad$ aerobic capacity, ventilatory threshold, team sports, football, handball, performance.
\end{abstract}

\section{Introduction}

Team sports such as soccer and handball area complex intermittent game requiring the repetition of high intensity activities with brief recovery periods $[1$, 2]. In soccer and handball, technical and tactical skills as well as the physical performance capacity of the player are most important factors that contribute to the success of a team in competitions. Competitive soccer and handball are a demanding sport that requires speed, agility, strength, muscular power and aerobic fitness $[3,4,5]$. Players require the ability to perform repeated maximal or near maximal intensity activities such as jumping, sprinting and changing of direction throughout the match $[6,7,8]$. The energy requirement is met by anaerobic metabolism during high intensity exercise periods while aerobic metabolism gains importance in order to supply homeostatic conditions at recovery intervals [9-11]. Improvements in aerobic capacity may not only be important for endurance performance, but also intermittent activities [9, 12].

Aerobic endurance is one of the main fitness components, important for success in soccer and handball $[7,13,14] . \mathrm{VO}_{2 \max }$ andanaerobic threshold (AT) are the most important parameters used in the evaluation of aerobic endurance $[6,15,16]$. Measurements of $\mathrm{VO}_{2 \max }$, which is defined as the highest oxygen uptake that can be achieved during dynamic exercise with large muscle groups [17], are widely used to assess an individual's capacity for the uptake, transport and utilization of oxygen [18]. During exercise, the oxygen consumption above which aerobic energy production is supplemented by anaerobic mechanisms, and which results in a significant (c) Mehmet Soyal, Selcen Korkmaz Eryılmaz, Metin Polat,

Sami Aydoğan, 2017

doi:10.15561/20755279.2017.0404 increase in lactate and metabolic acidosis, is termed the AT [19]. AT can be determined from non-invasive gas exchange measurements alternative to the measurements of blood lactate concentration (lactate threshold), in this case referred to as the ventilatory threshold [20, 21]. Ventilator anaerobic threshold corresponds to the nonlinear increase in carbon dioxide production $\left(\mathrm{VCO}_{2}\right)$ and ventilation due to the bicarbonate buffering of hydrogen ions $\left(\mathrm{H}^{+}\right)$in response to the systematic increase of blood lactate above resting values [21].

Physiological measurements of $\mathrm{VO}_{2 \max }$ and AT have commonly been used to monitor the training status of athletes and can help to determine the training regime [16, 22]. Knowing the $\mathrm{VO}_{2 \max }$ and AT values of the athletes may be important in terms of contributing to the understanding the physiological requirements of different sport branches. The purpose of this study was to determine differences in $\mathrm{VO}_{2 \max }$ and AT values of soccer and handball players.

\section{Material and methods \\ Participants}

Ten male handball players from the Second Turkish Division and ten male soccer players from the Third Turkish Division volunteered to participate in the study. The demographic characteristics of football and handball players are given in Table 1.The Erciyes University Ethics Committee approved the study (2013/693). All testing procedures were fully explained, and written informed consent was obtained for each subject. All measurements took place at the High Altitude and Sports Science Research and Implementation Center at Erciyes University. All the tests were conducted at the end of the season.

Cardiopulmonary exercise test 
The $\mathrm{VO}_{2 \max }$ and AT values of the athletes were determined from a progressive intensity and continuous effort treadmill protocol (h/p/Cosmos Quasar med, Nussdorf-Traunstein, Germany). Oxygen uptake $\left(\mathrm{VO}_{2}\right)$, carbon dioxide output $\left(\mathrm{VCO}_{2}\right)$ and minute ventilation were measured on-line using a breath-by-breath cardiopulmonary exercise testing system (Quark PFT Ergo, Cosmed Srl, Rome, Italy). Before each test, ambient conditions were measured and the gas analyzers and turbine flowmeter were calibrated with known certified gas concentrations $\left(16 \% \mathrm{O}_{2}, 5 \% \mathrm{CO}_{2}\right.$, and balance $\left.\mathrm{N}_{2}\right)$ and a 3-litre (L) calibration syringe, respectively, following the manufacturer's instructions. During the incremental testing period, heart rate (HR) was monitored continuously using a wireless HR monitor (Polar RS800 SD, Finland) and was synchronized to ventilatory signals. Breath-by-breath $\mathrm{VO}_{2}$ was smoothed using a five-step average filter, and then reduced to $15 \mathrm{~s}$ stationary averages (Data Management Software, Cosmed, Rome, Italy) to reduce the noise so as to enhance the underlying characteristics [23].

To make sure the players were properly warmed up, prepared, and accustomed to the treadmill, each participant had to warm-up for $6 \mathrm{~min}$ at their own pace. Then the players were allowed to stop and stretch for about $3 \mathrm{~min}$. Following the warm-up, players started running at $7 \mathrm{~km} / \mathrm{h}$ ( $0 \%$ slope) with speed increments of $1 \mathrm{~km} / \mathrm{h}$ every minute until they could no longer keep pace. The players were instructed to run until voluntary exhaustion, and given strong verbal encouragement throughout the test to elicit their best performance. The $\mathrm{VO}_{2 \max }$ was defined as the highest $15 \mathrm{~s} \mathrm{VO}_{2}$ value reached during the incremental test. Achievement of $\mathrm{VO}_{2 \max }$ was considered as the attainment of at least two of the following criteria: 1) a plateau in $\mathrm{VO}_{2}$ despite increasing speed, 2) a respiratory exchange ratio above 1.10 , and 3 ) a HR (heart rate) within 10 beats per minute of age-predicted maximum HR (220age) [24].

The $\mathrm{VO}_{2 \max }$ values were expressed as absolute value $\left(\mathrm{ml} \mathrm{kg}^{-1}\right)$ and relative value (milliliters per minute per body mass; $\mathrm{ml}^{-1} \mathrm{~kg}^{-1} \mathrm{~min}^{-1}$ ). Time to exhaustion was recorded as the time from the start of the run until the point of exhaustion (the time at which the subject could no longer maintain the pace of the treadmill). AT was estimated noninvasively using the V-slope method ${ }^{20}$, which depends upon the increase in $\mathrm{CO}_{2}$ output due to the excess $\mathrm{CO}_{2}$ production from bicarbonate buffering of metabolic acidosis compared to the $\mathrm{O}_{2}$ uptake during the incremental exercise test [21]. The values of $\mathrm{VO}_{2}\left(\mathrm{AT}_{\mathrm{VO} 2}\right)$, heart rate $\left(\mathrm{AT}_{\mathrm{HR}}\right)$, time $\left(\mathrm{AT}_{\mathrm{TIME}}\right)$ and running speed $\left(\mathrm{AT}_{\mathrm{SPEED}}\right)$ corresponding to the AT were determined. In addition, the data related to AT were expressed as a percentage of $\mathrm{VO}_{2 \max }\left(\mathrm{AT} \% \mathrm{VO}_{2 \max }\right)$ and $\mathrm{HR}_{\text {max }}\left(\mathrm{AT} \% \mathrm{HR}_{\max }\right)$.

Statistical analyses

Data are reported as means \pm standard deviation (SD). Statistical significance was accepted at $\mathrm{p}<0.05$. The normality of the data was examined by assessing the Shapiro-Wilk test on all measured variables. Ages, $\mathrm{AT}_{\mathrm{VO} 2}$, $\mathrm{AT}_{\mathrm{HR}}$ and $\mathrm{AT} \% \mathrm{VO}_{2 \max }$ data were not normally distributed and so comparisons between the groups were made using the Whitney-U test. As the other data showed normal distribution, the differences in measures between groups were evaluated by unpaired t-test. The SPSS version 16 was used for all analyses (16, SPSS Inc. Chicago, IL). Linear regression analyses were performed by using the Sigma Plot program (SigmaPlot 12.0, Systat Software Inc., Chicago, USA) to determine the anaerobic thresholds of the athletes.

\section{Results}

The physical characteristics of both groups are presented in Table 1. There were no significant differences between the age, height, body mass and sports ages of soccer players and handball players compared to each other $(\mathrm{p}>0.05)$. There were no significant differences between the two groups in the time to exhaustion(min), $\mathrm{HR}_{\text {max }}$, absolute $\mathrm{VO}_{2 \max }\left(\mathrm{ml} \mathrm{min} \mathrm{m}^{-1}\right)$ and relative $\mathrm{VO}_{2 \max }(\mathrm{ml}$ $\left.\mathrm{kg}^{-1} \mathrm{~min}^{-1}\right)(\mathrm{p}>0.05$; Table 2$)$. Similarly there were no statistically significant difference between the two groups

Table 1 The physical characteristics of the handball and soccer players (Mean \pm SD)

\begin{tabular}{llll}
\hline & Handball Players & Soccer Players & $\mathbf{p}$ \\
\hline Age (year) & $23.1 \pm 5.17$ & $22.3 \pm 3.68$ & 0.51 \\
Height $(\mathrm{cm})$ & $188.2 \pm 8.92$ & $181.7 \pm 5.01$ & 0.60 \\
Body Mass (kg) & $85.9 \pm 12.76$ & $77.4 \pm 8.34$ & 0.09 \\
Sport age (year) & $14 \pm 6.73$ & $13.3 \pm 3.43$ & 0.77 \\
\hline
\end{tabular}

Table 2 Cardiopulmonary exercise test results of handball and soccer players (Mean \pm SD)

\begin{tabular}{|c|c|c|c|}
\hline & Handball Players & Soccer Players & $p$ \\
\hline $\mathrm{VO}_{2 \max }\left(\mathrm{ml} \mathrm{kg}^{-1} \mathrm{~min}^{-1}\right)$ & $48.72 \pm 4.17$ & $50.87 \pm 5.91$ & 0.36 \\
\hline $\mathrm{VO}_{2 \max }^{2 \max }\left(\mathrm{ml} \mathrm{min}^{-1}\right)$ & $4138.4 \pm 351.3$ & $3901.2 \pm 506$ & 0.10 \\
\hline Time to exhaustion (min) & $9.76 \pm 1.48$ & $9.99 \pm 1.70$ & 0.75 \\
\hline $\mathrm{HR}_{\text {max }}\left(\right.$ beat $\min ^{-1}$ ) & $188.4 \pm 10.6$ & $196.4 \pm 8.6$ & 0.82 \\
\hline Relative $\mathrm{VO}_{2}$ at AT $\left(\mathrm{ml} \mathrm{kg}^{-1} \mathrm{~min}^{-1}\right)$ & $37.56 \pm 4.13$ & $40.68 \pm 8.98$ & 0.49 \\
\hline Absolute $\mathrm{VO}_{2}^{2}$ at AT $\left(\mathrm{ml} \mathrm{min}^{-1}\right)$ & $3215.8 \pm 506$ & $3074.5 \pm 606.9$ & 0.57 \\
\hline AT $\% \mathrm{VO}_{2 \max }{ }^{2}$ & $77.2 \pm 7.1$ & $79.6 \pm 11.2$ & 0.70 \\
\hline $\mathrm{HR}$ at $A T^{2 \max }$ & $160.9 \pm 7$ & $170.5 \pm 17$ & 0.10 \\
\hline AT \% HR & $85.5 \pm 3.3$ & $86.6 \pm 5.6$ & 0.58 \\
\hline Time at AT (min) & $4.13 \pm 1.5$ & $4.96 \pm 1.97$ & 0.30 \\
\hline Speed at AT $\left(\mathrm{km} \mathrm{h}^{-1}\right)$ & $10.7 \pm 1.56$ & $11.6 \pm 2.06$ & 0.28 \\
\hline
\end{tabular}


in the $\mathrm{AT}_{\text {SPEED }}\left(\mathrm{km} \mathrm{h}^{-1}\right), \mathrm{AT}_{\text {TIME }}(\mathrm{min}), \mathrm{AT}_{\mathrm{HR}}$, absolute $\mathrm{AT}_{\mathrm{VO} 2}$ $(\mathrm{ml} \mathrm{min}-1)$, relative $\mathrm{AT}_{\mathrm{VO} 2}\left(\mathrm{ml} \mathrm{kg}^{-1} \mathrm{~min}^{-1}\right), \mathrm{AT} \% \mathrm{VO}_{2 \max }$ and AT $\% \mathrm{HR}_{\text {max }}(\mathrm{P}>0.05)$.

\section{Discussion}

Athletes with high $\mathrm{VO}_{2 \max }$ and AT can more easily tolerate high intensity exercise, and perform exercise for longer periods of time in homeostatic conditions [10, 11 , $12,25]$. Physiological measurements of $\mathrm{VO}_{2 \max }$ and AT are important for monitor the training status of athletes, and determining the optimal training intensity [16, 22]. In the present study, there were no significant differences between the two groups in the time to exhaustion, $\mathrm{VO}_{2}$ and AT, suggesting that the aerobic endurance levels of soccer and handball players may be similar. Although soccer and handball require different movement patterns, they may exhibit similar aerobic endurance capacity. Hence physiological requirements in both branches may be expected to be similar in relation to training volume and intensity.

In order to be able to comment on the aerobic capacity, it is necessary to evaluate together the whole factors that determine the rate and amount of use of oxygen at tissue level. The analysis of the respiratory gas exchange with cardiopulmonary exercise tests give the opportunity to assess the cellular, cardiovascular and pulmonary responses to metabolic stress created during exercise $[17,18] . \mathrm{VO}_{2 \max }$ is regarded as the best determinant of aerobic capacity and important criterion affecting aerobic endurance performance $[4,18]$. There is a limited number of studies in the literature comparing aerobic capacities of soccer players and handball players with each other by cardiopulmonary exercise tests. Our findings have shown that there are no significant difference absolute $\mathrm{VO}_{2 \max }\left(\mathrm{ml} \mathrm{min}{ }^{-1}\right)$ and relative $\mathrm{VO}_{2 \max }\left(\mathrm{ml} \mathrm{kg}{ }^{-1} \mathrm{~min}^{-1}\right)$ values between soccer and handball players with similar sports ages and physical characteristics. In contrast to our findings, Malacko et al. showed that the $\mathrm{VO}_{2 \max }$ values of soccer players in the first league were higher than handball players in the first league [26]. On the other hand, it is seen that in their study $\mathrm{VO}_{2 \max }$ values (55.32 $\mathrm{ml} \mathrm{kg}{ }^{-1} \mathrm{~min}^{-1}$ ) of soccer players are higher than soccer players participated in our study [26]. This difference may be due to the fact that soccer players played in the third league and handball players played in the second league in our study. Similarly, Ferreira et al. showed that $\mathrm{VO}_{2 \text { peak }}$ values of young (age 17.7 years) and professional (age 23.2 years) soccer players were significantly higher than those of handball players (age 19 years) [27]. During a 90 -minute soccer match, players run about $10 \mathrm{~km}$ at an average $80-90 \%$ of maximal heart rate [28]. On the other hand, during a 60-minute handball match, players run about 4 to $6 \mathrm{~km}$ at a mean intensity close to $80-90 \%$ of maximal heart rate [29]. This information suggests that intensity of game in both branches similar, but that there may be differences in aerobic endurance performances of athletes when the duration of the game or the distance covered is taken into consideration.

In soccer and handball, players perform different types of physical activities requiring muscular power such as the various sprints, jumps, and quick changes of direction. The players' success depends on ability to repeatedly these physical activities at maximal or near maximal efforts with limited recovery over the duration of a match $[1,2]$. Players require well-developed aerobic capacity to maintain maximal performance throughout the match and to recover faster during the short periods of lower intensity or rest $[9,11,12]$. The handball players with a higher $\mathrm{VO}_{2 \max }$ can run at higher speeds during a match and can sprint more [14]. In the literature, it is seen that the handball players' $\mathrm{VO}_{2 \max }$ values measured by the cardiopulmonary exercise tests have different results. Our findings were consistent with those of Vujkov et al. reported that professional handball players' $\mathrm{VO}_{2 \max }$ values are $48.4 \mathrm{ml} \mathrm{kg}^{-1} \mathrm{~min}^{-1}$ [30]. On the other hand, Sporis et al. reported that $\mathrm{VO}_{2 \max }$ values of elite handball players are $54 \mathrm{ml} \mathrm{kg}{ }^{-1} \mathrm{~min}^{-1}$ [31]. Similarly, Buchheit et al. reported

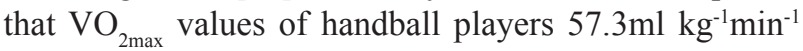
[32]. Previous studies have shown a significant correlation between $\mathrm{VO}_{2 \max }$ and distance covered during a soccer match [33, 34]. Similar to our findings, Clark et al. (2008) reported that the $\mathrm{VO}_{2 \max }$ values of professional male soccer players were $49.5 \mathrm{ml} \mathrm{kg}^{-1} \mathrm{~min}^{-1}$ [35]. On the other hand, in the literature, there are many studies showed that the $\mathrm{VO}_{2 \max }$ values of professional soccer players are higher than our findings [26, 28, 36, 37]. It can be suggested that the differences in the $\mathrm{VO}_{2 \max }$ values in the literature may be due to the difference in the training levels of the players.

Because of the difference in the metabolic systems in which energy is obtained during exercise, the intensity of exercise corresponding to AT must be known for the interpretation of performance and the preparation of the scientific training program. Exercise intensity corresponding to AT varies according to the physical conditioning of athlete. AT is considered an important criterion in assessing aerobic endurance [7, 16]. In the present study, there were no significant difference between the heart rate, time, running speed, absolute $\mathrm{VO}_{2}(\mathrm{ml} \mathrm{min}-$ ${ }^{1}$ ) and relative $\mathrm{VO}_{2}\left(\mathrm{ml} \mathrm{kg}^{-1} \mathrm{~min}^{-1}\right)$ values at the AT of soccer players and handball players. When AT expressed as a percentage of $\mathrm{VO}_{2 \max }$ and $\mathrm{HR}_{\max }$, it was also seen that there were no significant difference between the AT values of soccer players and handball players. Ferreira et al. showed that there was no significant difference between the running speed and heart rate at the AT of young soccer players and handball players. ${ }^{28}$ On the other hand, they found that the running speed and heart rate at the AT of professional soccer players were significantly higher than both groups [27]. These results suggest that the level of league played by players may be a determinant of $\mathrm{VO}_{2 \max }$ and AT.

There are a limited number of studies examining the anaerobic threshold values of handball players. In the study by Pontaga et al. professional handball players' AT values $\left(41.1 \mathrm{ml} \mathrm{kg}^{-1} \mathrm{~min}^{-1}, 88.7 \% \mathrm{VO}_{2 \max }, 91 \% \mathrm{HR}_{\max }\right.$ ) of determining by blood lactate measurements, were higher than our handball players [38]. The reason this may be 
attributed to differences in the measurement techniques. As a matter of fact, in their study [38], $\mathrm{VO}_{2 \max }(46.4 \mathrm{ml}$ $\mathrm{kg}^{-1} \mathrm{~min}^{-1}$ ) values of handball players in the first league seem to be similar to our study group. It is seen that in the literature, different results are revealed in the studies that determine AT with the gas exchange methods in soccer players. Similar to our research findings, Al Hazzaa et al. determined $\mathrm{VO}_{2}$ values at AT of elite football players as $43.60 \mathrm{ml} \mathrm{kg}^{-1} \mathrm{~min}^{-1}$ [39]. In the study by Clark et al. professional soccer players' $\mathrm{VO}_{2}$ values at AT $\left(34.1 \mathrm{ml} \mathrm{kg}^{-}\right.$ $\left.{ }^{1} \mathrm{~min}^{-1}\right)$ were lower than our handball players [35]. In the study by Chin et al. AT values $\left(47.2 \mathrm{ml} \mathrm{kg}^{-1} \mathrm{~min}^{-1}\right)$ of the professional soccer players were higher than our soccer players [36]. In another study, Casajus et al. reported that $\mathrm{VO}_{2}$ values at AT of soccer players playing in the first league of Spain were $50.2 \mathrm{ml} \mathrm{kg}^{-1} \mathrm{~min}^{-1}$ [37]. This difference in $\mathrm{VO}_{2}$ values at $\mathrm{AT}$ may be due to the $\mathrm{VO}_{2 \max }$ values of the soccer players (59.1 and $65.5 \mathrm{ml} \mathrm{kg}^{-1} \mathrm{~min}^{-1}$, respectively) in these studies were higher than in our study group $[36,37]$. On the other hand, when AT expressed as a percentage of $\mathrm{VO}_{2 \max }(80 \%$ and $77 \%$, respectively) $[36$, 37 ], it is seen that the difference between the findings of our study and these studies disappears. Similarly, other studies have shown that professional soccer players' AT occurred at $76 \%$ [39] and $80 \%$ of $\mathrm{VO}_{2 \max }$ [16]. In addition, when AT of the soccer players is expressed as a percentage of $\mathrm{HR}_{\max }$, it is seen that our findings are similar to those found $\left(85.6-89 \% \mathrm{HR}_{\max }\right)$ in previous studies [36, 37, 39].

\section{References}

1. Bangsbo J. The physiology of soccer - with special reference to intense intermittent exercise. Acta Physiol Scand. 1994;151:619

2. Buchheit M, Mendez-Villanueva A, Quod M, at al. Improving Acceleration and Repeated Sprint Ability in Well-Trained Adolescent Handball Players: Speed Versus Sprint İnterval Training. Int J Sports Physiology Perform. 2010;5:152-164.

3. Pinasco A., Carson J. Preseason conditioning for college soccer. J Strength Cond Res. 2005;27:56-62.

4. Hoff J, Helgerud J. Endurance and Strength Training for Soccer Players. Sports Med 2004;34:165-180.

5. Boraczyński T, Urniaż J. Changes In Aerobic And Anaerobic Power Indices In Elite Handball Players Following A 4-Week General Fitness Mesocycle, J Hum Kinet. 2008;19:131-140.

6. Helgerud J. Maximal oxygen uptake, anaerobic threshold and running economy in women and men with similar performance levels in marathons. Eur J Appl Physiol. 1994;68:155-61.

7. Helgerud J, Engen LC, Wisloff U, at al. Aerobic Endurance Training improves Soccer Performance. Med Sci Sports Exerc. 2001;33:1925-31.

8. Rannou F, Prioux J, Zouhal, at al. Physiological profile of handball players. J Sports Med Phys Fitness. 2001;4:349353.

9. Hamilton AL, Nevill ME, Brooks S, at al. Physiological responses to maximal intermittent exercise: differences between endurance-trained runners and games players. $J$ Sport Sci. 1991;9:371-382.

10.Balsom PD, Gaitanos GC, Ekblom B, et al. Reduced oxygen availability during high intensity intermittent exercise impairs performance. Acta Physiol Scand. 1994;152:279-85.

11.Glaister M. Multiple sprint work: physiological responses,

\section{Conclusions}

In the present study, no significant difference was observed between $\mathrm{VO}_{2 \max }$ and AT values of professional soccer players and handball players, suggesting that the aerobic endurance levels of soccer and handball players may be similar. These findings suggest that although, soccer and handball are different sports branches in terms of game rules and technical features, the players in both branches may be performing similar training loads (intensity and volume). On the other hand, considering that the duration of the soccer game is longer than the handball and the playing field is larger, it can be expected that the aerobic capacities of the soccer players are higher than handball players. The fact that the soccer and handball players in this study competing in the third and second division of the league respectively, may be a factor for their similar level of aerobic capacities. It is suggested that detailed studies related to aerobic capacity should be carried out on soccer players and handball players playing in different divisions.

\section{Funding/support}

No financial or grant support was received for this work.

\section{Conflicts of interest}

The authors have no conflicts of interest relevant to this study.

mechanisms of fatigue and the influence of aerobic fitness. Sports Med. 2005;35:757-77.

12.Tomlin D, Wenger H.A. The relationship between aerobic fitness and recovery from high intensity intermittent exercise. Sports Med. 2001;31:1-11.

13.Hoff J, Wisløff U, Engen LC, at al. Soccer specific aerobic endurance training. Br J Sports Med. 2002;36(3):218-21.

14. Manchado C, Pers J, Navarro F, at al. Time-Motion analysis in women's team handball: importance of aerobic performance. J Hum Sport Exerc. 2013;8:376-390.

15.Pate RR, Kriska A. Physiological basis of the sex difference in cardiorespiratory endurance. Sports Med. 1984;1:87-98.

16.Edwards A.M, Clark N, Macfadyen A.M. Lactate and ventilatory thresholds reflect the training status of professional soccer players where maximum aerobic power is unchanged. J Sports Sci Med. 2003;2:23-9.

17. Wagner PD. Determinants of maximal oxygen transport and utilization. Annu Rev Physiol. 1996;58:21-50.

18. Saltın B, Astrand P. Maximal oxygen uptake in athletes. $J$ Appl Physiol. 1967; 23:353-358.

19. Wasserman K. The anaerobic threshold measurement to evaluate exercise performance. Am. Rev. Respir. 1984;129:35-40.

20.Beaver WL, Wasserman K. Whipp BJ. A new method for detecting the anaerobic threshold by gas exchange. J Appl Physiol. 1986;60:2020-2027.

21.Wasserman K, Whipp BJ, Kogal SN, at al. Anaerobic threshold and respiratory gas exchange during exercise. $J$ Appl Physiol. 1973;35:236-43.

22.Cunha G, Lorenzi T, Sapata K, at al. Effect of biological maturation on maximal oxygen uptake and ventilatory thresholds in soccer players: an allometric approach. $J$ Sports Sci. 2011;29:1029-39. 
23.Myers J, Walsh D, Sullivan M, Froelicher V. Effect of sampling on variability and plateau in oxygen uptake. J Appl Physiol. 1990;68:404-410.

24.Howley ET, Bassett DR Jr, Welch HG. Criteria for maximal oxygen uptake: Review and commentary. Med Sci Sports Exerc. 1995;27:1292-130.

25.Allen WK, Seals DR, Hurley BF, at al. Laktate threshold and distance-running performance in young and older endurance athletes. J Appl Physiol. 1985;58:1281-1284.

26. Malacko J, Doder D, Djurdjević S, at al. Differences in the bioenergetic potential of athletes participating in team sports. Vojnosanit Pregl. 2013;70(7):633-6.

27.Ferreira RCA, Souza FB, Ribeiro W, at al. Analysis of Power and Aerobic Capacity in Elite Athletes of Both Genres, Practitioners of Different Sports. Advances in Physical Education. 2014:4:202-207.

28.Stolen T, Chamari K, Castagna C, at al. Physiology of soccer: An update. Sports Med. 2005;35(6):501-536.

29.Loftin M, Anderson P, Lytton L, at al. Heart rate response during handball singles match-play and selected physical fitness components of experienced male handball players. $J$ Sports Med Phys Fitness. 1996;36(2):95-9.

30.Vujkov S, Đukic M, Drid P. Aerobic capacity of handball players with hearing impairment. Biomed Hum Kinetics. 2010;2:58-61.

31.Sporiš G, Vuleta D, VuletaJr D, at al. Fitness Profiling In Handball: Physical and Physiological Characteristics of Elite Players. Coll Antropol. 2010;34:1009-1014.
32.Buchheit M., Lepretre P.M., Behaegel A.L., Millet G.P., Cuvelier G., Ahmaidi S. Cardiorespiratory responses during running and sport specific exercises in handball players. $J$ Sci Med Sport. 2009;12:399-405

33.Bangsbo J. Energy demands in competitive soccer. J Sports Sci. 1994;12:5-12.

34.Smaros G. Energy usage during a football match. In: Vecciet $\mathrm{L}$, ed. Proceedings of the First International Congress on Sports Medicine Applied to Football. Rome: Guanillo D. 1980;795-801.

35.Clark NA, Edwards AM, Morton RH, Butterly RJ. Seasonto-season variations of physiological fitness within a squad of professional male soccer players. J Sports Sci Med. 2008;7:157-165.

36.Chin MK, Lo YS, Li CT, et al. Physiological profiles of Hong Kong elite soccer players. Br J Sports Med. 1992;26(4):2626.

37.Casajus JA. Seasonal variation in fitness variables in professional soccer players. J Sports Med Phys Fitness. 2001;41(4):463-9.

38.Pontaga I, Zidens J. Comparison of anthropometric and performance characteristics in amateur and professional level handball players. LASE J Sport Sci. 2012;3 (1):47-54.

39.Al-Hazzaa HM, Al-Muzaini KS, Al-Refaee, at al. Aerobic and Anaerobic Power Characteristics of Saudi Elite Soccer Players. J Sports Med Phys Fitness. 2001;41:54-61.

\section{Information about the authors:}

Mehmet Soyal; http://orcid.org/0000-0001-6528-0275; mehmetsoyal3838@hotmail.com; School of Physical Education and Sports, Sakarya University; Sakarya University Esentepe Campus 54187 Serdivan, Sakarya, Turkey.

Selcen Korkmaz Eryılmaz; http://orcid.org/0000-0002-3680-3580; selcen_korkmaz@yahoo.com; School of Physical Education and Sports, Cukurova University; 01330 Balcali, Saricam. Adana. Turkey.

Metin Polat; http://orcid.org/0000-0001-7299-0531; polat.metin@gmail.com; School of Physical Education and Sports, Erciyes University; Erciyes University T Block, TR-Kayseri Kayseri, Turkey.

Sami Aydoğan; http://orcid.org/0000-0003-3230-5864; aydogans@erciyes.edu.tr; Division of Sports Physiology, Department of Physiology, Faculty of Medicine, Erciyes University; Erciyes University T Block, TR-Kayseri Kayseri, Turkey.

Cite this article as: Mehmet Soyal, Selcen Korkmaz Eryılmaz, Metin Polat, Sami Aydoğan. Comparison of maximal oxygen uptake and anaerobic threshold in soccer and handball players. Physical education of students, 2017;21(4):171-175. doi: $10.15561 / 20755279.2017 .0404$

The electronic version of this article is the complete one and can be found online at: http://www.sportedu.org.ua/index.php/PES/issue/archive

This is an Open Access article distributed under the terms of the Creative Commons Attribution License, which permits unrestricted use, distribution, and reproduction in any medium, provided the original work is properly cited (http://creativecommons.org/licenses/by/4.0/deed.en).

Received: 13.06.2017

Accepted: 25.06.2017; Published: 10.08.2017 